\title{
Pathogenicity of Brazilian strains of Ralstonia solanacearum in Strelitzia reginae seedlings
}

\author{
Lucas M.R. Rodrigues, Suzete A.L. Destéfano, Maria Celeste T. Diniz, Renata Comparoni \& Júlio \\ Rodrigues Neto
}

Laboratório de Bacteriologia Vegetal, Instituto Biológico, 13012-970, Campinas, SP, Brazil

Author for correspondence: Lucas M.R. Rodrigues, e-mail: lucasmriverorodrigues@gmail.com

\begin{abstract}
Twenty four strains of Ralstonia solanacearum belonging to races 1, 2 and 3 of biovars I, II and III, isolated from various hosts were investigated for their ability to cause disease on Strelitzia seedlings through artificial inoculation. Results revealed that, with one exception, only strains isolated from plants of Musa or Heliconia (classified as race 2) caused wilt symptoms on Strelitzia, indicating their pathogenic potential to that plant species. Seedlings of Strelitzia could be used as test plants for presumptive diagnosis for banana Moko disease.

Key words: diagnosis, inoculation, moko, wilt symptoms.

\section{RESUMO}

Patogenicidade de estirpes brasileiras de Ralstonia solanacearum em mudas de Strelitzia reginae

Vinte e quatro estirpes de Ralstonia solanacerum provenientes de vários hospedeiros foram avaliadas por meio de inoculação artificial para sua capacidade em causar doença em mudas de Strelitzia. Os resultados revelaram, com uma exceção, que apenas as estirpes isoladas de Musa ou Heliconia (classificadas na raça 2) causaram sintomas de murcha em Strelitzia, indicando seu potencial patogênico para essa espécie vegetal, ou pelo menos, que mudas de Strelitzia podem ser utilizadas como planta teste para o diagnóstico presuntivo da doença Moko da bananeira.

Palavras-chave: diagnóstico, inoculação, Moko, murcha bacteriana.
\end{abstract}

Ralstonia solanacearum is considered one of the most important bacterial plant pathogen, causing the bacterial wilt disease in more than 200 plant species belonging to 54 different botanical families (Elphinstone, 2005). This bacterial species has a high pathogenic and genetic diversity and these characteristics are used for the classification at infrasub specific level into five biovars (Bv) based on carbohydrate utilization, and five races (R) based on the pathogenicity to different hosts (Buddenhagen et al., 1962; Hayward, 1991; Boucher et al., 2006). It can also be grouped into phylotypes or monophyletic clusters, distinguished based on the analysis of nucleotide sequences of multiple genomic regions: the ITS region and the $\operatorname{hrpB}$ (a regulator of type 3 secretion system) (Poussier et al., 1999), Egl (endoglucanase, a virulence factor) and MutS (a DNA mismatch repair enzyme) genes (Fegan \& Prior, 2005; Prior \& Fegan, 2005).

$R$. solanacearum strains differ considerably in host range as well as on aggressiveness to different hosts. For instance, race 1 strains (R1) have a very wide host range including numerous ornamentals, and are present in most regions of the globe, while race 2 (R2) strains are pathogenic to Musa spp and ornamental Heliconia spp, occurring in tropical areas of the Central and South America, Hawaii and Philippines (Kelman, 1953; Bradbury, 1986; Elphinstone,
2005). The race 3 (R3) or biovar II (BvII) strains are pathogenic mainly to potato and eventually infect tomato or other solanaceous hosts, including weeds, as well as geraniums; race 4 (R4) affects ginger (Pegg \& Moffett, 1971) and race 5 (R5) is pathogenic to mulberry (He et al., 1983). The relationship among them is evident only in the R3 strains which are correlated with BvII (Hayward, 1991). In Brazil, $R$. solanacearum is widely distributed and marked by a great variety of hosts, including several species of ornamental and weed plants (Malavolta Jr. et al., 2008).

Regarding pathogenicity to ornamentals, the literature describes Strelitzia reginae (family Strelitziaceae, formerly Musaceae) as a host of $R$. solanacearum in Hawaii (Quinon \& Agaraki, 1963) Japan (Liu et al., 2009) and Australia (Moffett, 1983), and these reports suggest that R1/BvIII was involved with the disease.

To investigate the behavior of Strelitzia reginae seedlings in relation to infectivity potential of Brazilian strains of $R$. solanacearum, pathogenicity tests were carried out through artificial inoculations with a set of 24 strains isolated from different hosts and regions of the country. Bacterial strains used in this study were obtained at the IBSBF Culture Collection and are classified as race 1,2 or 3 and are listed in Table 1. For the inoculation experiments, 
TABLE 1 - Origin of $R$. solanacearum strains examined in this study

\begin{tabular}{|c|c|c|c|c|}
\hline \# IBSBF * & Host & Locality & Race/Biovar & Phylotype \\
\hline 33 & S. lycopersicon & Indaiatuba - SP & $1 / \mathrm{I}$ & IIA \\
\hline 134 & S. tuberosum & Itutinga - MG & $3 /$ II & II \\
\hline 172 & S. tuberosum & Santa Juliana - MG & $3 / \mathrm{II}$ & - \\
\hline 187 & Musa sp. & Humaitá - AM & $2 / I$ & IIA \\
\hline 188 & Musa sp. & Humaitá - AM & $2 / \mathrm{I}$ & IIA \\
\hline 615 & Musa sp. & Pará & $2 / \mathrm{I}$ & - \\
\hline 623 & Eucalyptus hib. & Jarí - PA & $1 / \mathrm{I}$ & IIA \\
\hline 891 & Musa sp. & Manaus - AM & $2 / \mathrm{I}$ & - \\
\hline 1543 & Musa sp. & Itacoara - AM & $2 / \mathrm{I}$ & IIA \\
\hline 1559 & Musa sp. & Coari - AM & $2 / \mathrm{I}$ & - \\
\hline 1828 & S. tuberosum & Bragança Paulista - SP & $1 / \mathrm{I}$ & - \\
\hline 1839 & Begonia hib. & Holambra - SP & $1 / \mathrm{III}$ & I \\
\hline 1882 & Begonia hib. & Atibaia - SP & $1 / \mathrm{III}$ & I \\
\hline 2000 & S. lycopersicon & Manaus- AM & $1 / \mathrm{III}$ & I \\
\hline 2001 & S. lycopersicon & Benjamin Constant - AM & $1 / \mathrm{I}$ & - \\
\hline 2131 & Eucalyptus urophylla & Carbonita - MG & $1 / \mathrm{I}$ & IIA \\
\hline 2569 & Musa sp. & Japoatã - SE & $2 / 1$ & IIA \\
\hline 2644 & Heliconia sp. & Abreu e Lima - PE & $2 / \mathrm{I}$ & IIA \\
\hline 2660 & Heliconia sp. & Abreu e Lima - PE & $2 / \mathrm{I}$ & IIA \\
\hline 2661 & Heliconia sp. & Abreu e Lima - PE & $2 / \mathrm{I}$ & IIA \\
\hline 2714 & S. lycopersicon & Coimbra - MG & $1 / \mathrm{I}$ & - \\
\hline 2715 & S. melongena & Cruz das Almas - BA & $3 /$ II & - \\
\hline 2725 & Musa sp. & Japoatã - SE & $2 / I$ & IIA \\
\hline 2834 & S. tuberosum & Mucugê - BA & $3 /$ II & - \\
\hline
\end{tabular}

*IBSBF $=$ Phytobacteria Culture Collection of the Instituto Biologico, Campinas, SP, Brazil.

- not determined

freeze-dried cultures were re-hydrated, and cultured on tetrazolium chloride (TZC) medium (Kelman, 1954). Virulent colonies were streaked onto nutrient agar (NA) medium and incubated at $28{ }^{\circ} \mathrm{C}$ for $48 \mathrm{~h}$. Colonies grown on NA were harvested into sterile distilled water and the cell suspensions adjusted to approximately $1 \times 10^{8}$ colony forming units $/ \mathrm{mL}$ concentration (OD $600 \mathrm{~nm}$ of 0.1 ) and used as inoculum.

Potted Strelitzia seedlings maintained in a greenhouse at the two to three expanded leaves stage were inoculated by wounding the youngest leaf axil with a sterile needle and pouring $30 \mu \mathrm{L}$ of bacterial suspension over the wounded tissue (Winstead \& Kelman, 1952). Control plants were treated similarly with sterile distilled water. Five plants were inoculated with each strain and evaluated weekly for symptom expression until eight weeks after inoculation. Plants showing symptoms were excised for microscope examination of the vascular system to confirm the systemic infection. Results are summarized in Table 2.

All R. solanacearum strains originated from Musa or Heliconia induced leaf chlorosis and/or wilting 4-8 weeks after inoculation (Figure 1A-B). These strains are all classified as R2/BvI. None of the plants inoculated with strains from other hosts (classified as R1 or R3) expressed any external symptom until the end of experiments, except the strain IBSBF 1828 (R1/BvI) isolated from potato, which induced wilt symptoms on leaves and two wilted plants after four weeks (Figure 2). One strain (IBSBF 134, R3/BvII) caused a limited infection in one plant near the inoculation site, eliciting stripes in the leaf (Figure 3), however no wilt symptom developed nor systemic infection was detected. All wilted plants examined under microscope showed bacterial colonization of the vascular system, including the roots adjacent to the cortex.

Although the literature report the occurrence of wilt disease on Strelitzia caused by $R$. solanacearum R1/BvIII strains in some countries, the results obtained indicate that with a single exception (strain IBSBF 1828 which showed highly virulence causing wilt four weeks after inoculation), only strains classified as R2 were able to infect the Strelitzia plants causing wilt symptoms.

$R$. solanacearum is a complex bacterial species and its virulence mechanisms are related to their genetic variability, and could be associated to several other factors, such as host range, geographic distribution, physiological properties, adaptation to different temperatures, and even spread by insects (Cellier \& Prior, 2010; Milling et al., 2009). In this case, the susceptibility of Strelitzia (formerly classified in Musaceae family) to $R$. solanacearum R2 strains is probably no due the acquisition of genes or adaptation of 
TABLE 2 - Number of the strain according time after inoculation and kind of symptom

\begin{tabular}{|c|c|c|}
\hline \multirow[t]{2}{*}{ Symptom } & \multicolumn{2}{|c|}{$\mathbf{N}^{0}$ of the strain } \\
\hline & four weeks a.i. ** & after eight weeks a.i. \\
\hline \multirow{12}{*}{ Symptomless } & $33(\mathrm{R} 1 / \mathrm{BvI})[5]^{*}$ & $33(\mathrm{R} 1 / \mathrm{BvI})[5]$ \\
\hline & 134 (R3/BvII) [4] & 134 (R3/BvII) [4] \\
\hline & 172 (R3/BvII) [5] & 172 (R3/BvII) [5] \\
\hline & $623(\mathrm{R} 1 / \mathrm{BvI})[5]$ & $623(\mathrm{R} 1 / \mathrm{BvI})[5]$ \\
\hline & 1839 (R1/BvIII) [5] & 1839 (R1/BvIII) [5] \\
\hline & 1882 (R1/BvIII) [5] & 1882 (R1/BvIII) [5] \\
\hline & 2000 (R1/BvIII)[5] & 2000 (R1/BvIII)[5] \\
\hline & $2001(\mathrm{R} 1 / \mathrm{BvI})[5]$ & $2001(\mathrm{R} 1 / \mathrm{BvI})[5]$ \\
\hline & 2131 (R1/BvI) [5] & 2131 (R1/BvI) [5] \\
\hline & 2714 (R1/BvI) [5] & 2714 (R1/BvI) [5] \\
\hline & 2715 (R3/BvII) [5] & 2715 (R3/BvII) [5] \\
\hline & 2834 (R3/BvII) [4] & 2834 (R3/BvII) [4] \\
\hline \multirow[t]{5}{*}{ Leaf chlorosis or distortion } & 134 (R3/BvII) [1] & 134 (R3/BvII) [1] \\
\hline & $1828(\mathrm{R} 1 / \mathrm{BvI})[1]$ & 2834 (R3/BvII) [1] \\
\hline & 2725 (R2/BvI) [4] & \\
\hline & 2834 (R3/BvII) [1] & \\
\hline & $2660(\mathrm{R} 2 / \mathrm{BvI})[1]$ & \\
\hline \multirow[t]{10}{*}{ One or two leaves wilted } & 187 (R2/BvI) [5] & \\
\hline & $188(\mathrm{R} 2 / \mathrm{BvI})[5]$ & \\
\hline & $615(\mathrm{R} 2 / \mathrm{BvI})[5]$ & \\
\hline & 891 (R2/BvI) [5] & \\
\hline & 1543 (R2/BvI) [5] & \\
\hline & $1559(\mathrm{R} 2 / \mathrm{BvI})[5]$ & \\
\hline & $2569(\mathrm{R} 2 / \mathrm{BvI})[5]$ & \\
\hline & $2644(\mathrm{R} 2 / \mathrm{BvI})[4]$ & \\
\hline & $2660(\mathrm{R} 2 / \mathrm{BvI})[3]$ & \\
\hline & $2661(\mathrm{R} 2 / \mathrm{BvI})[3]$ & \\
\hline \multirow[t]{12}{*}{ Plants wilted } & $1828(\mathrm{R} 1 / \mathrm{BvI})[4]$ & 187 (R2/BvI) [5] \\
\hline & $2644(\mathrm{R} 2 / \mathrm{BvI})[1]$ & $188(\mathrm{R} 2 / \mathrm{BvI})[5]$ \\
\hline & $2660(\mathrm{R} 2 / \mathrm{BvI})[1]$ & $615(\mathrm{R} 2 / \mathrm{BvI})[5]$ \\
\hline & $2661(\mathrm{R} 2 / \mathrm{BvI})[2]$ & 891 (R2/BvI) [5] \\
\hline & $2725(\mathrm{R} 2 / \mathrm{BvI})[1]$ & $1543(\mathrm{R} 2 / \mathrm{BvI})[5]$ \\
\hline & & 1559 (R2/BvI) [5] \\
\hline & & $1828(\mathrm{R} 1 / \mathrm{BvI})[5]$ \\
\hline & & 2569 (R2/BvI) [5] \\
\hline & & 2644 (R2/BvI) [5] \\
\hline & & $2660(\mathrm{R} 2 / \mathrm{BvI})[5]$ \\
\hline & & $2661(\mathrm{R} 2 / \mathrm{BvI})[5]$ \\
\hline & & 2725 (R2/BvI) [5] \\
\hline
\end{tabular}

* Number in brackets indicates the number of plants for each strain.

** After inoculation 

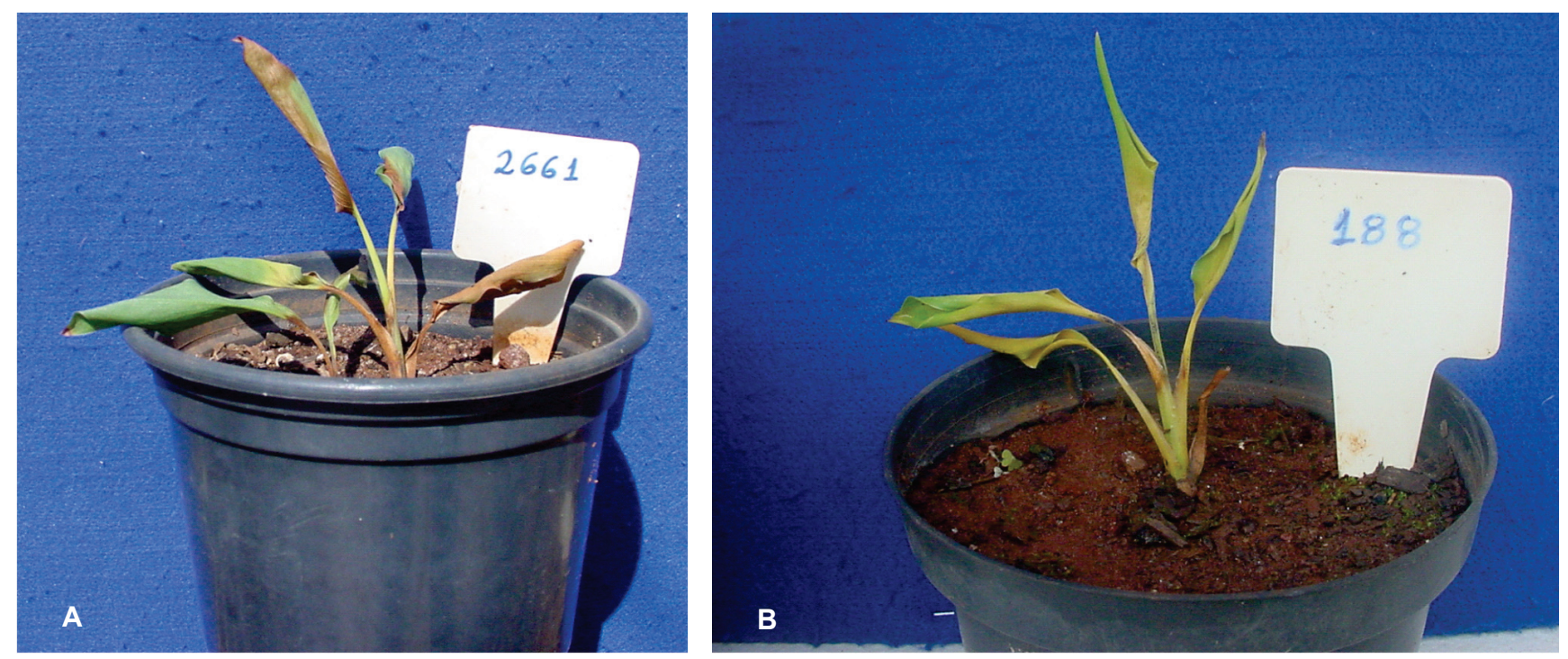

FIGURE 1 - Wilt symptoms induced by Ralstonia solanacearum strains IBSBF 2661 (R2/BvI) and IBSBF 188 (R2/BvI) four weeks after inoculation.

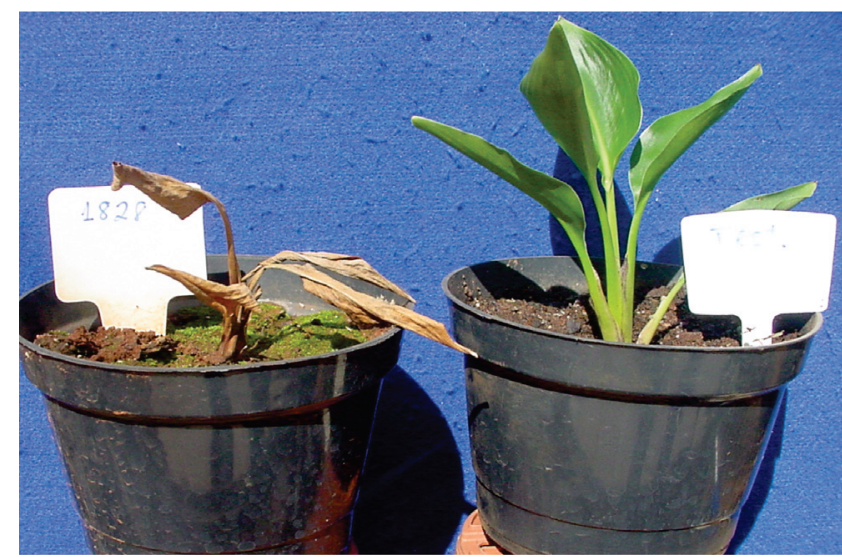

FIGURE 2 - Wilt symptoms induced by Ralstonia solanacearum strain IBSBF 1828 (R1/BvI) four weeks after inoculation; right, control plant inoculated with distilled water.

the pathogen, but to natural host susceptibility to R2 strains. Thus, the results obtained indicated that Strelitzia could be used at least, as a test plant for the presumptive diagnosis of banana Moko disease.

\section{REFERENCES}

Bradbury JF (1986) Guide to the plant pathogenic bacteria. Surrey UK. CAB International Mycological Institute.

Boucher C, Guidot A, Carrère S, Peeters N, Elbaz M, Prior P, Genin S (2006) Genomic variability and evolution in Ralstonia solanacearum. Abstracts, The $4^{\text {th }}$ International Bacterial Wilt Symposium. York UK. p. 23.

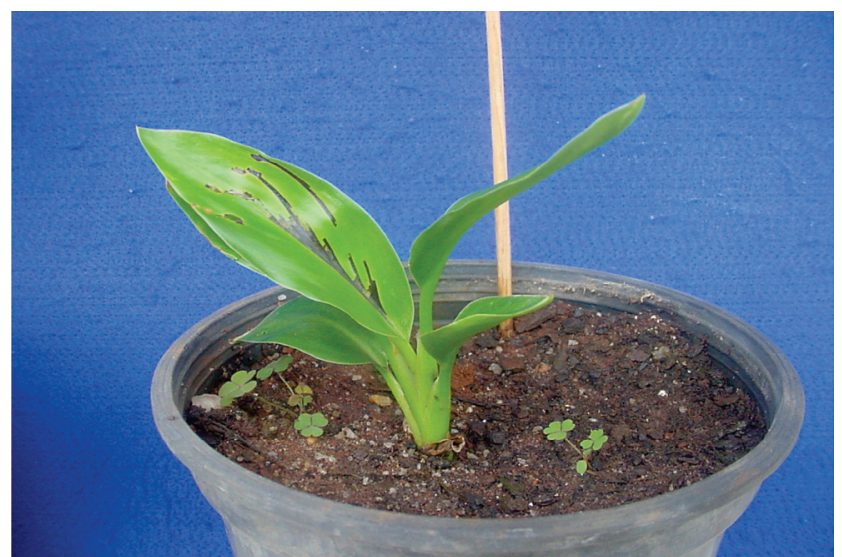

FIGURE 3 - Stripe symptoms elicited by Ralstonia solanacearum strain IBSBF 134 (R3/BvII).

Buddenhagen I, Sequeira L, Kelman A (1962) Designation of races in Pseudomonas solanacearum. Phytopathology 52:726.

Cellier G, Prior P (2010) Deciphering phenotypic diversity of Ralstonia solanacearum strains pathogenic to potato. Phytopathology 11:1250-1261.

Elphinstone JG (2005) The current bacterial wilt situation: a global overview. In: Allen C, Prior P, Hayward AC (Eds.) Bacterial wilt disease and the Ralstonia solanacearum species complex. St. Paul USA. American Phytopathological Society. pp. 9-28.

Fegan M, Prior P (2005) How complex is the "Ralstonia solanacearum species complex"? In: Allen C, Prior P, Hayward AC (Eds) Bacterial wilt disease and the Ralstonia solanacearum species complex. St. Paul USA. American Phytopathological Society. pp. 449-461. 
Hayward AC (1991) Biology and epidemiology of bacterial wilt caused by Pseudomonas solanacearum. Annual Review of Phytopathology 29:65-87.

Hayward AC (1994) The hosts of Pseudomonas solanacearum. In: Hayward AC; Hartaman GL (Eds.) Bacterial wilt: the disease and its causative agent, Pseudomonas solanacearum. Wallingford UK. CAB International. pp. 9-24

He LY, Sequeira L, Kelman A (1983) Characteristics of strains of Pseudomonas solanacearum from China. Plant Disease 67:135711361.

Kelman A (1953) The bacterial wilt caused by Pseudomonas solanacearum. A literature review and bibliography. Raleigh USA. North Carolina Agricultural Experimental Station, Technical Bulletin 99. pp. 194.

Kelman A (1954) The relationship of pathogeniciity in Pseudomonas solanacearum to colony appearance on a tetrazolium medium. Phytopathology 44:693-695.

Liu Y, Kanda A, Yano K, Kiba A, Hikichi Y, Aino M, Kawaguchi A, Mizoguchi S, Nakaho K, Shiomi H, Takikawa Y, Ohnishi K (2009) Molecular typing of Japanese strains of Ralstonia solanacearum in relation to the ability to induce a hypersensitive reaction in tobacco. Journal of General Plant Pathology 75:369-380.

Malavolta Jr. VA, Beriam LOS, Almeida IMG, Rodrigues Neto J, Robbs CF (2008) Bactérias fitopatogênicas assinaladas no Brasil: uma atualização. Summa Phytopathologica 34:9-88.
Milling A, Meng F, Denny TP, Allen C (2009) Interactions with hosts at cool temperatures, not cold tolerance, explain the unique epidemiology of Ralstonia solanacearum Race 3 Biovar 2. Phytopathology 99:1127-1134.

Moffett ML (1983) Bacterial plant pathogens recorded in Australia. In: PC Fahy \& GJ Persley (Eds.) Plant Bacterial Diseases - A Diagnostic Guide. Sidney Australia. Academic Press. pp. 317335.

Pegg K, Moffett ML (1971) Host range of the ginger strain of Pseudomonas solanacearum in Queensland. Australian Journal of Experimental Agricultural and Animal Husbandry 11:696-698.

Poussier S, Vandewalle P, Luisetti J (1999) Genetic diversity of African and worldwide strains of Ralstonia solanacearum as determined by PCR Restriction Fragment Length Polymorphism analysis of the hrp gene region. Applied and Environmental Microbiology 65:2184-2194.

Prior P, Fegan M (2005) Recent developments in the phylogeny and classification of Ralstonia solanacearum. Acta Horticulturae 695: 127-136.

Quinon VL \& Aragaki M (1963) Bacterial wilt of bird-of-paradise caused by Pseudomonas solanacearum. Phytopathology 53:11151116.

Winstead NN, Kelman A (1952) Inoculation techniques for evaluating resistance to Pseudomonas solanacearum. Phytopathology 42:628-634.

TPP 326 - Received 17 May 2011 - Accepted 17 January 2012 Section Editor: Marcos A. Machado 